\title{
Changes in media consumption and its impact in modern advertising: a case study of advertising strategies in Ecuador
}

\section{Cambios en el consumo de medios y su impacto en la publicidad moderna: un estudio de caso de estrategias publicitarias en Ecuador}

Melissa Valeria Espinoza Mata

Norman Cevallos Polanco

Aleksandar Tusev

Universidad de Especialidades Espíritu Santo, Ecuador

Autor por Correspondencia: meliespinozam@gmail.com, ncevallosp@uees.edu.ec, atusev@uees.edu.ec

Fecha de recepción: 4 de Abril de 2017 - Fecha de aceptación: 5 de Junio de 2017

Resumen: El marketing digital se ha convertido en una herramienta esencial para las agencias de publicidad modernas. Cualquier empresa seria que no tome nota de esta realidad está en peligro de quedar obsoleta. Los medios sociales han tomado protagonismo con los milennials, ofreciendo a los anunciantes oportunidades de crecimiento viral. Como tal, los hábitos de consumo de los medios están cambiando cada vez más rápido en todo el mundo. En Ecuador, el mercadeo digital comienza a ser tomado en serio, pero todavía no está ocupando la atención óptima para captar el nicho de mercado milenario que seguramente existe. Este estudio analiza la transición del marketing tradicional al digital, con un análisis de caso de Ecuador, una nación latinoamericana en proceso de modernización. Además, la investigación aquí describe los nuevos conceptos implementados en la industria y busca identificar si el marketing digital reemplazará a los medios tradicionales en un futuro cercano. Con el fin de analizar estos temas, se realizaron entrevistas con expertos de la industria. Como resultado, se encontró que el marketing digital no se ha utilizado a una tasa de maximización, en su lugar el enfoque ha seguido siendo en las estrategias de comercialización más tradicionales. Esta estrategia ha demostrado ser aún la más segura y eficaz en este mercado; Sin embargo, los anunciantes necesitan comenzar a planificar cambios dinámicos, que gran parte del mundo occidental ya ha pasado a, o tienen el riesgo de quedarse atrás.

Palabras Clave: Ecuador; marketing digital; marketing 2.0; marketing en medios tradicionales; social media; millennials

\begin{abstract}
Digital Marketing has become an essential tool for modern advertising agencies. Companies that do not consider this fact are in danger of becoming obsolete. Social media has taken center stage with millennials, offering advertisers viral growth opportunities. As such, media consumption habits are changing ever faster worldwide. In Ecuador, digital marketing is beginning to be taken seriously, yet it is still not occupying the optimal attention in order to capture the millennial market niche that surely exists. This study analyses the transition from traditional to digital marketing, with a case study analysis of Ecuador, a Latin American nation in the process of adopting these modern advertising tools. Furthermore, the research here describes the new concepts implemented in the industry and seeks to identify if digital marketing will replace traditional media any time soon. In order to analyze these topics, interviews with industry experts were conducted. As a result, it was found that digital marketing
\end{abstract}


has not been used at a rate of maximization, instead the focus has continued to be on more traditional marketing strategies. This strategy has proven to still be the safest and most effective one in this market; however, advertisers need to start planning for dynamic shifts that much of the Western world has already moved on to, or risk the possibility of being left behind.

Key words: Ecuador; digital marketing; social media; traditional marketing; marketing 2.0; millennials

\section{Introduction}

Media consumption habits are changing faster than anyone would have predicted only decades ago (Chang, 2016). Technological networks and marketing are evolving; therefore, companies need to pay due attention to the emerging trends and marketing tools available if they are to capture and persuade the niche millennial consumer. The onset of the digital age has created new lifestyles and new habits of consumption among younger generations who are embracing the use of digital media devices as the primary means for communication. According to PR Newswire (2016), tools like social media and email have created alternative methods for pitching media in addition to traditional cold-calls. Therefore, as news and information consumption habits change, it is harder to attract the attention of younger audiences (Newswire, 2016).

Kotler (1999) stated: "Marketing is a race without a finishing line"; therefore, marketers have to be updated and ahead of their competitors to survive this new era, as digital marketing is becoming a tool that if ignored, will lead to grave conclusions. As Ogilvy (1963) observed, "An advertisement is like a radar sweep, constantly hunting new prospects as they come into the market. Get a good radar, and keep it sweeping". The same people marketers advertised to yesterday would not be the same ones that marketers will need to reach tomorrow. Traditional Marketing strategies have been the only medium implemented to target the millennial niche market. Millennials born in the digital era from 1980 to 2000 are a different generation requiring a new approach. Marketers have to constantly innovate their campaigns to remain relevant in the eyes of these observant consumers.

An ongoing debate ensues over whether digital marketing is overwhelming and overcoming traditional marketing. There are analysts that believe digital marketing has taken the lead, and it is only a matter of time before traditional marketing becomes a relic. However, there are also proponents of traditional marketing that warn not to stray too far from a tool that is time tested and proven so successful for so long.

It is the aim of this study to analyze this contested debate over the traditional and digital marketing mix in a time where millennials are truly digital information consumers. This debate is now a global one for sure. As such, this study will offer additional data to the existing array of studies by analyzing the little known marketing industry of an emerging nation in Latin America: Ecuador. This will be done by conducting private interviews with marketing managers from well-known local advertising agencies; inquiries will be made over what the impact of new technological tools on the millennial market niche have been, and the prospects for digital marketing in a traditional marketing dominated market. Furthermore, interviews will establish how current traditional marketing is being aimed at targeting younger audiences. 
This is an exploratory paper and it will try to find out if traditional marketing will be replaced by digital marketing to target the millennial market niche in the near future. Also, it will discuss the new digital marketing era and it will explain the new channels and trends like viral marketing, mobile marketing, social networks that have been created in this last decade and it will examine some marketing strategies that are used in digital media and preferred by millennials. A limitation of this study is the sample of five experts; there are many more reputable directors that would also have been valuable sources.

\section{Literature review}

\section{The new age of digital marketing}

Over the past decade, marketing has evolved from a traditional or conventional approach to a digital approach. Petouhoff stated (2016), "What social and digital devices have done is really transform marketing, customer service, and even sales". In order for a company to be competitive, they must constantly change and renew themselves, adjusting to the new changes of technology. According to Muñoz (2016), marketers will need to alter the company's culture to deliver relevant, seamless digital experiences to customers. With the onset of the internet and wifi connected world, companies need to pay more attention to updating their website, design, content and user management in order to provide a dynamic service to clients. Marketers who want to succeed in building brand awareness today are finding that they have no choice but to include digital branding in their plans. However, the task is proving to be a challenging one.

Traditional marketing strives to serve and capture loyal clients, as well as succeed in every commercial transaction instead of only trying to gain value in the long term. Furthermore, it determines price according to the highest cost instead of the objective price that the client is willing to pay. Such traditional marketing makes use of the marketing mix tools of product, price, promotion, and place separately instead of holistically. The new marketing era recognizes that products need to be adapted to what the market wants. Products and services need to make permanent innovations, and create loyal and positive relations with clients; traditional media has been the fundamental basis for carrying out several advertising campaigns for many years; due to radio, printed press and television, several brands are known and have achieved great success in sales. According to Fry (2016), "'Longevity is the main reason why people are accustomed to traditional marketing;" they are pretty much everywhere, from billboard ads to TV commercials; the thing is that people are so used to it that sometimes it doesn't feel like it is everywhere.

Modern marketing strives to create value to clients. Marketers have been concentrating on using social media as an additional tool for their client's goals. According to Stelzner (2015), a significant $47 \%$ of marketers who have more than 3 years' experience spend at least 16 hours per week focused on social media activities. Brands have begun to take advantage of this interaction with social networks, fan pages, internet advertising and other Web 2.0 tools.

Digital marketing has introduced new concepts including communication 2.0, social networking, engagement marketing, branded communities, advertisement, blogvertising, positioning, viral marketing, mobile marketing and social marketing. 


\section{Digital marketing channels}

The Concept communication 2.0 has its origin in the World Wide Web. O'Reilly, founder of O'Reilly publishing House Media, and one of the drivers of free software, coined the term 2.0 to refer to a new generation in the history of the web, based on user communities and services like the already famous social networks. These encourage collaboration and exchange of information among users for free. Communication 2.0 is a new way to relate to the audiences (MGA Consultores, 2009). It is a revolution to social relations; a new environment where the protagonist is the user, who has stopped being a passive information receiver to become a content producer (Gross, 2009).

\section{Social networks}

Digital social networks are a globally increasingly phenomenon. They are being used by companies as marketing tools due to the ease and low cost they represent in aspects such as communication, information and the relationship with the client (Uribe, 2010). Social networks, virtual social networks or social network sites are a service based on a web platform that allows people to build a public or semi-public profile within a bounded, articulate system with a list of other users with whom they wish to share a connection (Boyd \& Ellison, 2007). The leading social networks of the day include Facebook, Twitter, LinkedIn, Blogger, and YouTube.

\section{Engagement Marketing}

Marketing commitment or the degree of consumer commitment to the brand is a new set of rules that puts business in continuous contact with customers, at any time, by any means. Engagement marketing proves that social media should be taken as seriously, if not more so, than any other marketing effort. It is necessary to get feedback, respond to questions, sell products and earn referrals. This makes e-mail the center of marketing strategies (Bishop \& Cellucci, 2010). Commitment marketing, then, seeks to measure the degree to which the markets generate expectations to the consumer that equal or surpass the experiences of the engagement.

\section{Branded Communities}

A brand community is a specialized body, with no geographical boundaries, based on a structured set of social relations among the admirers of a brand (Muniz \& O'guinn, 2001). These groups of consumers or potential customers of a particular brand, create loyalty to it. Brand communities are a growing phenomenon on the internet that is driving notable changes in consumer behavior (Casaló, Blanco, \& Guinalíu).

\section{Advertainment}

Advertainment, also called branded content, is a symbiosis between advertising and entertainment content whose main objective is to attract the public to the values of a brand in an attractive way (Ramos, 2009). To develop a good strategy of advertainment, it should follow a simple rule: Entertain. 


\section{Blogvertising}

Blogvertising is the use of blogs as an advertising medium. According to Pc magazine (2016), it is placing ads on a blog in a subtle way. Although blogs have traditionally not displayed advertising, ads are increasingly included. A blog can be a very promising tool for companies that want to implement an alternative to build the public image or observe what content their recipients generate about their brands, products, services or at their social concerns. Among the main characteristics of blogs are that it provides readers the ability to "post their comments" to bloggers' posts comments that in turn can be read and quoted by other readers. The reader interprets the opinion of a blogger as the opinion of a friend, a member of his family or a consumer, and therefore gives more value than the references of an institutional blog of a company (Olamedi, 2014). People can now compare and share opinions much faster than before, which speeds up the impact of public opinion on business.

\section{Viral Marketing}

In 1997, Steve Hurveston coined the term viral marketing, when in an article published in Netscape M-Files, he spoke of the spectacular success developed by Hotmail became a hit in record time as the largest provider of web-based e-mail services. Viral marketing is a technique that allows the dissemination of a marketing message, starting from a small emitting nucleus, which is multiplied by the collaboration of the receivers in the transmission and diffusion of the same, generating a pyramidal progression effect that grows geometrically (Cerrada, 2005). It is a marketing strategy that relies on users to forward, share, and communicate brand action. These can be games, music, photos, videos, news or creative ideas. Viral marketing offers high visibility at low prices and helps build brand image, although its outcome is not mathematical and depends on users (Interactive Advertising Bureau, 2012).

\section{Mobile Marketing}

Mobile marketing allows ubiquitous communication for its ability to be everywhere, as it is a portable medium. Communication through this medium is instantaneous and almost pent sensorial as it transmits the word, sound, music, still image and moving (Fernandez V., 2006). The main characteristics and advantages of mobile marketing include that it is personal, ubiquitous, interactive, allows an immediate and synchronous communication; It is also integral in the global communication strategy and it allows for viral marketing (Rodriguez L. M., 2011). Viral marketing campaign consist of many types: (Varas, 2010) Mobile SMS Marketing, Alerts, SMS Interactivity/Viral Marketing, SMS Trivia, MMS Campaign, Mobile Sites, Applications, Barcode Campaigns, Bluetooth or Proximity Marketing Campaigns, Broadcast, Micro Payment, Contents, and Mobile Games. Paul Fleming (year), recognized internet marketing, and president of Barcelona Virtual (the first interactive advertising agency in Spain) coined the term "4Fs" to refer to the similarity of the "4Ps" of traditional marketing. These refer to Flow, Functionality, Feedback and Loyalty (ANETCOM, 2007).

\section{Ad blockers}


Ad blockers are a filter that removes online ads and trackers. Privacy badger is an extension of browsers that blocks ad trackers that follows from one site to another.

This new software is the biggest disadvantage that digital marketing has at the moment. Digital advertising content can be avoided and millennials from different countries are embracing the use of it. (Rowe, 2016) There is no actual number of people that uses it but it is growing in some parts of the world. Ad blockers are available for computers and mobiles phones.

\section{Traditional marketing}

Traditional Marketing has a longevity hard to compete with. From billboard to magazine ads to radio jingles to TV commercials, traditional media has been part of most generations. They focus on a local audience or segmented target rather than an abroad one and it can be considered as a tangible form of marketing with flyers, business cards, newspapers and magazines. If implemented in right way, traditional marketing could have faster results, durability and a great level of trust from the buyer (Todor, 2016). It needs a substantial time and budget to get the desired results.

\section{Marketing for millennials}

Millennials are considered a generation born between 1980 and 2000, creating a new niche market. According to Investopedia (2015), millennials are the first generation born into the digital world. They are different to other generations because they are more willing to create their own jobs rather than working for someone else. According to the U.S. Census Bureau Statistics (2015), millennials will shape the job market for the next three decades. They are one of the most promising generations to date; they are highly educated, think businesses need to focus more on social issues than profit, and because of them companies are evolving digitally. Millennials do not look for jobs with long hours, they like to feel that they have completed their goals, so they look for a job with challenges and projects that are not far-reaching because they are demotivated.

It's challenging to get the attention of millennials. According to Swanson (2016), millennials have a very short attention span. They have a diversity of information than any other generation available to them. According to Watson (2015), "Humans have a shorter attention span than goldfish, thanks to smartphones" it has made people's attention fall, because they are more interested in their devices and all the apps that it offers than paying attention to actual human beings. They can multitask, save time and be more productive, but this can become distracting because they need instant gratification. This span of attention is really challenging for marketers who need to create awareness in a short period of time. According to Bryan University (2016), Millennial switch their attention between media platforms 27 times per hour. They multitask a lot during work hours, checking emails, doing phone calls, chatting, listening to music, drinking coffee, doing a report and even checking their social media. They say it could be beneficial to multitask in a few activities because it makes the brain think faster. The important thing is to know when to multitask and when not to.

Ecuadorian Millennials are not just interested in a brand selling them a product, but also what that brand is doing for communities (Chavarria, 2015). This generation cares about the 
environment and human development. Millennials are defining a new and successful marketing world order that is digital centric, social-first, and driven by video. (Genauer, 2016). Marketing to millennials has its own set of rules, not only does it need to have an online strategy but brands need to deliver on promises. Donoughe (2016) stated that $84 \%$ of millennials think they can digest the whole brand story at first glance. That is why packaging needs to be optimized. They are also looking to build a relationship with the brand. The disadvantage of only relying on digital is that millennials do not like digital advertising and some of them use ad- blockers on their devices (Emarketer, 2016).

\section{Ecuador's current media landscape}

According to the Institute of Statistics and Censuses (INEC, 2015), in $201546.35 \%$ of people in Ecuador had access to the internet. This has almost doubled in 2016, with 83.8\% internet users (Internet World Stats, 2016), The Ministry Of Telecommunications (2015), stated that this growth is mainly due to the increase in the percentage of households with internet access, as well as the government's public policies in providing internet in public places such as state educational institution. The usage of internet in Guayaquil and Quito has increased from $75 \%$ in 2012 to $90 \%$ in 2015; it has become an ubiquitous tool which has made social media a new marketing tool to advertise products and services (Mercaper, 2015). This is part of a campaign to prioritize and democratize universalize access to information and communication technologies. This growth is mainly due to the increase in the percentage of households with internet access, as well as the government's public policies in providing internet to public places such as state educational institutions etc., within its priority to democratize and universalize access to information and Communication Technologies.

According to Conactel (2016), in Ecuador there are 894 radios and 494 television channels. Radio continues to be the most important media with the most coverage, credibility in all regions of the country. However, only the $8 \%$ percent of the population that listens radio, listens to the news. Most people listen to music and sports programs.

There is controversy over whether traditional media will be displaced or subordinated to the rise of digital media. Drastic changes have already been seen in other parts of the world, where traditional media has been pushed back due digital media. According to Karp (2015), there are radio stations in the US that are having a hard time making a profit in this digital era. For sure they still have an audience but the advertising budgets are shifting online. They had to reduce their prices in order to compete with online advertising that is cheaper, especially talk show radios because few brands don't want to be associated with any controversial topic that they air. It also reflects that younger audiences prefer digital media. In other countries like Norway the situation is more drastic, as Petroff (2017), stated that FM radios are in a shutdown process and will be switched to digital only by the end of 2017.

In Ecuador, traditional media is still relevant and the king of advertising, for now. The biggest advantage that digital media has is the ability to quantify it easily. This helps advertisers identify how many people watch ads, measure how many people are clicking on a website, what days, what times and more. Marketers can recognize which sections are most popular, what consumers are looking for, the things they say and the things they share. On the other hand, a 
disadvantage that digital marketing is facing is the use of ad blockers. Consumers are not the same as they were before, and therefore they are highly trained in technology. Increasingly, internet users look for ways to avoid online advertisements. In traditional media advertising was avoided through zapping, but it is not as aggressive as ad blockers online that can erase ads completely.

In Ecuador, advertising expenditure has declined over the last two years. As Info media stated in 2014, investment on traditional media (TV, radio, newspapers, billboards and magazines) was $\$ 440$ million; that's $\$ 13$ million less than in 2013 , including political campaign expenditures. TV is the most bought media, supplying $60 \%$ of the market. While print media occupies $17 \%$, radio $12 \%$ and billboards and magazines share the remaining $11 \%$ of the investment. This demonstrates that Ecuadorians still consume media via traditional channels. According to Maruri (2015), television is the most popular media because every Ecuadorian family has one and watches it regularly. Inec (2016), stated that an Ecuadorian spends at least one hour and a half watching TV. The biggest advantage is that there are just a few national channels; that's why companies trust the impact of this media. Printed media advertising grossed profits of $\$ 81.5$ million in 2013 ; this declined to $\$ 71.5$ million in 2014 . Radio is still an important media for advertising as jingles are one of the best ways for a customer to remember a brand. The investment in radio increased to $\$ 54.7$ million in 2013 than the previous year, while billboards and magazines had a revenue of \$24. 9 in 2013 million. On the other hand, IAB Ecuador (2015), stated that the expenditure of online advertising was \$7.4 million, mainly targeting younger audiences. Even though online expenditure is growing, television is still the favorite media for advertisers.

\section{Methodology}

\section{Importance of the Study}

The importance of this study is that it will discuss the new digital marketing channels that could be used to target the millennial market niche.

Consequently, this study seeks to validate new marketing strategies implemented by advertising agencies in Ecuador, especially its focus on the millennial market niche. In addition, there is a gap in literature as to the future of traditional media, which depends on large advertising budgets compared to relatively cheaper digital tools. The mix of digital marketing strategies and traditional marketing is a subject that has received little attention in academia in Ecuador. Therefore, this niche will be explored in order to provide more basic structure to the ongoing issue.

\section{Type of Research}

This research takes on an exploratory type; the study will be conducted by interviewing managers from five advertising agencies in Guayaquil, Ecuador, specialized in traditional and digital marketing. The aim of the interviews was to discover how digital marketing strategies are implemented and if they will affect mass media or traditional media campaigns. 
Furthermore, this paper analyzes the causes of the growth of digital marketing, and its effect on millennials. Some specific points that were discussed include whether digital marketing will replace traditional media such as television, radio, newspapers and magazines, and what is expected to be seen in the workplace.

A qualitative study was chosen as in order to get more insights and more detailed information of this seldomly studied topic. The executives were from Guayaquil. Also, a statistical study form Mercaper (2015) about the impact of social media in Guayaquil was analyzed. This discussed how people consume social media, and how companies can implement social media advertising to different social groups.

\section{Methods of data collection}

To carry out this research, a total of 5 advertising executives where interviewed from the following companies: Ariadna Ecuador, Maruri, Intelligence and Marca Diferenciada, The information gathered was qualitative with the use of open questions. The first interviewee is Pedro Vargas president of the Intelligence digital advertising agency. He is the creative director and is in charge of all the strategies implemented. The second interviewee is Alejandro Cedeño, cofounder of Marca Diferenciada digital agency. He is the owner of the agency. The third interviewee is with Estefania Correa digital director of Ariadna Ecuador. She is in charge on the media buying decision and strategies implement for each client. These executives were selected for the interviews because of their vast knowledge on the topics of digital marketing, social media campaigns, sales and projections in Guayaquil, Ecuador. The remaining two interviewees also have a vast knowledge on mass media campaigns and sales. Their opinion is important because they know the trends for targeting the millennial market niche.

The Mercaper social media study of Guayaquil was bought up in order to analyze the statistical data it contains regarding the impact of traditional mass media and modern media tools used in Guayaquil in 2015.

\section{Analysis of results}

The results of the qualitative questions were presented in summary form and in a table. The answers that represented the most significant information given were tabulated. Also, the results had statistical data collected from a previous study on social media; this information was interpreted in the charts. The full set of questions can be seen in Appendix A.

\section{Limitations}

The interviewees chosen were done so based on reputations of the agencies. However, there are many additional reputable agencies that may also be as valid to offer expert testimony.

\section{Results}

Table number 1 - A summary of the interview elaborated by the author. 


\begin{tabular}{|c|c|c|c|c|c|c|}
\hline & ANSWERS & Person 1 & Person2 & Person3 & Person4 & Person5 \\
\hline & \multicolumn{6}{|c|}{ 1. What do you think about digital marketing as a new tool for advertising? } \\
\hline & Necessary & $x$ & $\mathrm{x}$ & $\mathrm{x}$ & $\mathrm{x}$ & $x$ \\
\hline & Not Necessary & & & & & \\
\hline & \multicolumn{6}{|c|}{ 2. Do you think digital marketing will be more important than traditional media? } \\
\hline & Yes & $x$ & $\mathrm{x}$ & $x$ & $\mathrm{x}$ & \\
\hline & No & & & & & $\mathrm{x}$ \\
\hline & \multicolumn{6}{|c|}{ 3. In how many years do you think digital will surpas traditional ? } \\
\hline U & 5 years & & $\mathrm{x}$ & & & \\
\hline & 8 years & $\mathrm{x}$ & & & $x$ & \\
\hline $\mathrm{E}$ & 10 years & & & $\mathrm{x}$ & & $x$ \\
\hline & \multicolumn{6}{|c|}{ 4. What media do you think will need to make some changes? } \\
\hline$S$ & TV & & $\mathrm{x}$ & $x$ & & \\
\hline$T$ & Radio & $x$ & & & & \\
\hline & Newspaper & & & $x$ & & \\
\hline 1 & Magazines & $\mathrm{x}$ & $\mathrm{x}$ & & $x$ & \\
\hline $\mathrm{O}$ & \multicolumn{6}{|c|}{ 5. According to you what should traditional media do to still be relevant? } \\
\hline & Livestreaming & $\mathrm{x}$ & $\mathrm{x}$ & $\mathrm{x}$ & & $\mathrm{x}$ \\
\hline N & Mobile Apps & $\mathrm{x}$ & & & $\mathrm{x}$ & $\mathrm{x}$ \\
\hline C & Interact in real time & & $\mathrm{x}$ & & & $\mathrm{x}$ \\
\hline 3 & Fan pages & $\mathrm{x}$ & $\mathrm{x}$ & $\mathrm{x}$ & & \\
\hline & \multicolumn{6}{|c|}{ 6. What are the advantages of digital marketing? } \\
\hline & Visual Storytelling & $\mathrm{x}$ & & $\mathrm{x}$ & & \\
\hline & Metrics & $\mathrm{x}$ & $\mathrm{x}$ & $\mathrm{x}$ & & \\
\hline & Millennials & & & & & \\
\hline & Low Cost & & $\mathrm{x}$ & $\mathrm{x}$ & & $x$ \\
\hline & \multicolumn{6}{|c|}{ 7. What are the advantages of traditional marketing? } \\
\hline & Durability & $\mathrm{x}$ & & $\mathrm{x}$ & $\mathrm{x}$ & $\mathrm{x}$ \\
\hline & Faster results & $\mathrm{x}$ & & & $\mathrm{x}$ & $\mathrm{x}$ \\
\hline & Level of trust & & $\mathrm{x}$ & $\mathrm{x}$ & & $\mathrm{x}$ \\
\hline & Reach & & & & $\mathrm{x}$ & $\mathrm{x}$ \\
\hline & \multicolumn{6}{|c|}{ 8. What are the preferences of the Ecuadorian Millennials? } \\
\hline & Internet & $\mathrm{x}$ & $\mathrm{x}$ & $\mathrm{x}$ & $\mathrm{x}$ & $\mathrm{x}$ \\
\hline & Mobile Apps & $\mathrm{x}$ & & $\mathrm{x}$ & $\mathrm{x}$ & $\mathrm{x}$ \\
\hline & Social causes & & $\mathrm{x}$ & & $\mathrm{x}$ & \\
\hline & \multicolumn{6}{|c|}{ 9- How do you get the attention of millennials? } \\
\hline & Social causes & $\mathrm{x}$ & $\mathrm{x}$ & & & \\
\hline & Multi channel & $\mathrm{x}$ & $\mathrm{x}$ & & $\mathrm{x}$ & $\mathrm{x}$ \\
\hline & Blogs & & $\mathrm{x}$ & $x$ & & \\
\hline & Mobile Friendly & $\mathrm{x}$ & $\mathrm{x}$ & $x$ & & $\mathrm{x}$ \\
\hline & Video content & $\mathrm{x}$ & $x$ & $x$ & & $x$ \\
\hline & Influencers & & $\mathrm{x}$ & & $\mathrm{x}$ & \\
\hline
\end{tabular}

The results from the marketing director's interviews demonstrated how digital marketing is evolving and how the internet consumption has changed advertising strategies. The results show that the majority of executives have seen an increase in their levels of advertising goals through an increase in social media interaction in sites like Facebook, Instagram, Youtube, Google, Hotmail and even sites such as El Universo, Ecuavisa, El Comercio, Estadio and El Noticiero. The interviews also indicate that while most advertising agencies still buy traditional media advertising like TV, Radio and Newspapers ads, they consider that the best way to advertise is by creating cross marketing between both channels. Digital Marketing was not relevant a few years ago in the country and not even considered as an important tool, but since the new features of social media and the increase of internet access in the country, Ecuadorian marketers are starting to realize digital marketing is becoming such an important new tool for modern advertising with a low cost expenditure. 
Pedro Vargas creative director of Intelligence agency stated that digital marketing could replace traditional marketing overtime. Metrics are the best advantage that digital marketing has over traditional marketing, because it shows how many people see the ad; it targets a segment that is desired, instead of old fashioned media that relies on ratings that are just a little portion of a study, and it is not as accurate as metrics. This makes a big difference. Digital marketing is cheaper than television ads and it has a high impact on younger audiences. Middle and upper class consumers are targeted easily than before. In addition companies can have real life interactions with customers that they could not have before. The Digital Marketing trends in Ecuador are content with an emotional storytelling focus, short videos, animations and gifs on social media sites such as facebook, youtube and instagram. They have a huge impact and awareness on millennials because they prefer brand stories that they can connect. There was a debate about whether digital will replace traditional marketing over time to target this niche market but, they can work together and create cross marketing. Eventually, in five to eight years everything around us will be more digital oriented and that is why traditional media needs to make some adjustments and have an online presence. Vargas also stated that blogvertising and mobile marketing are the best strategies to catch the attention of millennials because they tend to follow the trends they see online so a blog with good content, can generate a high impact. The use of influencers is not popular in the country as it is in other parts of the world but it is good strategy that brands can implement. Depending on the brand, viral marketing is also a good strategy because it has a low cost with a huge impact.

Estefania Correa media director of Ariadna Ecuador agency stated that digital marketing has real time results, greater exposure, and engagement, in contrast traditional marketing has been part of our life for so long that a world without it would be hard to find. It would be difficult to find a street without billboards as it would be cars without radios. All marketing channels are equally important, it depends on the brand's goals, and which one fits them better. There are products that need traditional marketing. Even the government needs it. So digital marketing is just another channel. Small businesses can benefit from this new and cheaper tool. Despite there still are millennials that use traditional media and watch tv commercials, listen to radios and at the same time they read a blog online. Traditional marketing has their own branding and standards. It would be hard to replace it.

Traditional media has been really successful throughout the years, even though it needs to do some adjustments in order to survive this new digital era. Alejandro Cedeño from Marca Diferencia agency argues that traditional media will need to have a stronger online presence by adding content to live streaming and needs to implement mobile apps as well. It is known that digital marketing is the future of modern advertising and an appropriate media for targeting millennials, as well as other specific segments. Marketers still will buy traditional channels over the years because it feels more tangible to consumers.

Cedeño stated that millennials are a huge market and they are going to be the largest consumer and employee force in a few years. They are using new technologies on their daily basis, that's why digital marketing needs to be taken more seriously in the country. It also depends on the brand, but small and medium business can benefit considerably from it. However millennials are a hard niche to persuade because they are a generation that is well informed and before buying a product they search it online. Campaigns need to be interesting, short and 
creative to attract their attention. Brands need to be careful with their online strategies because a pop up ad can be intrusive and, it could generate a negative perception of the brand. Millennials are a generation that wants everything faster, so an interruption could do the opposite that is expected. In other parts of the world millennials are implementing ad blockers to avoid excessive advertising, so cross marketing is the most effective form for advertising in this new era because in the end we are living in a physical world, so traditional and digital are as equal as important and they need to work together for better results.

\section{Discussion}

Although digital marketing proved to be the most developed and modern tool for creating awareness to the millennial market niche and increasing a company client's base, it is still not the best option yet, because over time millennials can avoid online advertising by installing ad blockers software on their devices, and that is a big disadvantage of this media. According to Cedeño cross media marketing should be considered the best alternative for an advertising campaign. The strategies of both channels, traditional and digital needs to be related and in a 360- degree approach plan. It means that the creative concept have to be the same in digital and traditional channels.

Traditional marketing should not be neglected in advertising budgets as it is still risky to just rely on a new marketing trend. Traditional marketing has had a high success rate over decades and there are still millennials that consume mass media channels. Costumers are smarter than before and as mentioned they could end up placing add blockers in their computers and mobile phones to avoid excessive advertising ads. Even though there is more internet access in Ecuador, millennials are not willing to see advertising on social media. Ads that interrupt a customer online can create negative feelings towards the brand, while these interruptions are expected on traditional media. Even though the use of digital marketing is growing, it can't replace traditional mass media marketing because Ecuadorians still use TV and radio on a daily basis. Overtime digital marketing will end up having the same level of importance for marketers but it won't completely replace traditional marketing. On the contrary traditional mass media needs to make most of their content online if they want to still be relevant to this market niche in five to ten years.

\section{Conclusion}

To conclude, the benefit of this study has been that it clarifies the doubts of the future of traditional marketing as well and the advantages of digital marketing in Ecuador. Digital channels are redefining marketing and is an important component in building a brand. Millennial's tool of consumption is their smartphones; that is why traditional media like radio needs to have their distributions in apps while TV needs be on demand, live streaming. All content today needs to be mobile friendly.

It was known before the study that digital marketing is replacing traditional marketing in other countries of the world. But in the case of Ecuador, it was discovered that advertising executives think that it is not safe to rely on one channel to target millennials because the Ecuadorian millennials are eager to try a product when it is covered by a media they trust like 
TV and radio. Nevertheless, it is important for marketers to know what the trends and channels to get the attention of the millennial market niche are. It was found out that millennials prefer storytelling and interactive ads on social media or you tube but dislike intrusive pop up ads. In the future, digital marketing will overcome traditional marketing if traditional media doesn't do anything to improve and attract younger generations. Marketers need to adapt to the millennials making up the bulk of the society's workforce. Learn what they respond to and what matters to them. It could just be the breakthrough their business needs to move forward into the future. Bartel (2015) stated that marketers have a responsibility to work even more diligently, to be even more creative of techniques, and to broaden their concepts considerably in this new era. The most important thing is that the marketing strategies have to be authentic for millennials to connect. This case study can be used as a reference point to other similar markets in Latin America. In the end, as Ogilvy (1990) said, what really makes consumers decide to buy or not is the content of advertising, not its form.

\section{Appendix}

\section{Appendix A: Interview questions}

1. Do you think digital marketing will replace traditional marketing in the near future?

2. What will happen to the traditional mass media?

3. Is Cross media marketing important?

4. What are the digital marketing trends in Ecuador?

5. Is viral marketing campaign the right way to promote a brand?

6. What are the digital marketing strategies used in Ecuador?

7. How traditional media should overcome this digital era?

8. What are the digital projections in Ecuador?

9. What are the advantages of digital marketing over old fashioned or traditional marketing?

10. How do you calculate the impact of digital campaigns?

11. How do you catch the attention of millenials online?

\section{Bibliography}

Andes. (2015, October 2). Ecuador uno de los países de américa latina en que más creció el acceso al internet en los últimos tres años. Retrieved from http://www.andes.info.ec/es/noticias/ecuador-uno-paises-america-latina-mas-crecioacceso-internet-ultimos-tres-anos.html

ANETCOM. (2007). Herramientas Online para el cambio de modelo productivo.

Arcotel. (2016). Servicios portadores de telecomunicaciones. Retrieved from http://www.arcotel.gob.ec/estadisticas-2/

Bartels, R. (2015). Sociologists and marketologists. Journal of marketing, 24(2), 37-40. Retrieved from http://web.b.ebscohost

Berners - Lee, T., Hendler, J., \& Lassila, O. (2001). The semantic web. Scientific, 284(5), 2837. 
Bishop, T., \& Cellucci, M. (2010). Total Engagement Marketing. Net Atlantic, 122-127.

Boyd, D., \& Ellison, N. (2007). Social Network Sites: Definition, History, and Scholarship. Journal of computer-mediated communication, 13(1), 210-230.

Casaló, L., Blanco, C., \& Guinalíu, M. (n.d.). Comunidades virtuales de marca, aspecto clave en la lealtad del consumidor. Universidad de Zaragoza.

Cerrada, R. (2005). Marketing viral: el efecto bola de nieve. Cuadernos de Marketing Inteligente.

Chang, A. (2015, April 14). Radical changes in media consumption are not slowing down. Retrieved from https://www.cyberlink.com

Del Rowe, S. (2016, July). Digital transformation requires a cultural change. CRM Magazine, 20(7), 15-15. Retrieved from http://web.a.ebscohost

Donoughe, L. (2016). What millennials want. Stateways, 46(6), 10-10. Retrieved from http://web.a.ebscohost.com/

El Emprendedor. (2015, December/January 2). Como son los millennials ecuatorianos. Retrieved from http://www.elemprendedor.ec/como-son-los-millennials-ecuatorianos/

Fry, R. (2016, April 25). Millennials overtake baby boomers as America's largest generation. Retrieved from http://www.pewresearch.org/

Genauer, R. (2016, November). Millennial marketers disrupt balance of marketing power. Retrieved from http://web.a.ebscohost.co

Gross, M. (2009, July 10). Comunicación 2.0: el dominio de los usuarios. Retrieved from http://manuelgross.bligoo.com/content/view/559850/Comunicacion-2-0-el-dominio-delos-usuarios.html\#.WHBLWFUrJ0w

Inec. (2010). Los ecuatorianos dedican una hora y media diaria en ver televisión. Retrieved from http://www.inec.gob.ec/inec/index.php?option=com_content\&view=article\&id=19\%3

Interactive Advertising Bureau. (2012). Glosario de Términos de publicidad y marketing digital.

Internet world stats. (2016). Ecuador's internet usage and market report. Retrieved from http://www.internetworldstats.com/sa/ec.htm

Karp, H. (2015, February 3). Talk radio's advertising problem. The wall street journal. Retrieved from http://www.wsj.com/articles/talk-radios-advertising-problem-1423011395

Kotler, P. (1999). El marketing según Kotler. Barcelona: Editorial Paidós. 
Kotler, P. (2008). Marketing in a changing world. In Principles of marketing (9th ed., p. 6) [EReader Version].

Mercaper. (2015). Estudio de mercado cualitativo y cuantitativo de medios de comunicacion y redes sociales de. Quito, Guayaquil: Author.

MGA Consultores. (2009). Comunicacion 20 [Blog post]. Retrieved from http://mgaconsultores.blogspot.com/

Muniz, A. M., \& O’guinn, T. C. (2001, March). Brand Community. Journal of Consumer research, Inc.

Muñoz, P. (2010). Funny Marketing. Consumidores, entretenimiento y comunicaciones de marketing en la era del branded entertainment. España: Wolters Kluwer.

Odell, P. (2016, October 13). Almost half of millennials are blocking ads: survey. Retrieved from http://web.a.ebscohost

Ogilvy, D (1963).Retrieved from http://www.ogilvy.co.za/quotes/radar-sweep/

Olamendi, $\quad$ G. $\quad$ (s.f.). $\quad$ Blogvertising. $\quad$ Retrieved from http://www.estoesmarketing.com/Comunicacion\%20alternativa/Blogvertising.pdf

Palazzesi, A. (2012). Prosumers, la revolución que viene. Retrieved from http://www.neoteo.com/prosumers-larevolucion-que-viene

Pc Magazine. (2016). Blogvertising. $\quad$ Retrieved from http://www.pcmag.com/encyclopedia/term/60671/blogvertising

Petouhoff, N., \& Rowe, D. (2016, May). How to succeed in real time marketing. CRM magazine, 20(5), p22-25. 4p. Retrieved from http://web.a.ebscohost.

Petroff, A. (2017, January 6). Norway is the first country to kill its fm radio network. Cnn. Retrieved from http://money.cnn.com/technology

PR Newswire. (2016, May 5). Relationships \& discoverability: earning more media for your clients. Retrieved from http://e.prnewswire.com/rs/prnewswire/images/SE-CO2.6.3_Relationships_And_Discoverability_Earning_More_Media_For_Your_Clients.pdf

Ramos, M. (2009). El advertainment y las transformaciones de los formatos en el ámbito publicitario: el caso de los fashion films. Tripodos extra.

Revista Lideres. (2015, March 22). La inversión publicitaria decae en medio de la irrupción digital. Revista Lideres, 1(1). Retrieved from http://www.revistalideres.ec/lideres/inversion-publicitaria-digital-ecuador.html 
Rodríguez, L. M. (2011). Claves para valorar el Marketing Móvil. Revista de Comunicación Vivat Academia, 51-62

Rowe, S. D. (2016). Ad Blocking War Heats Up. CRM Magazine, 20(10), 13. Retrieved from http://web.a.ebscohost.

Schwab, K. (2016). historical context. In The forth industrial revolution (p. 7). Retrieved from http://www3.weforum.org/docs/Media/KSC_4IR.pdf

Stelzner, M. (2011). Social media marketing industry report; how marketers are using social media to grow their businesses (1). Retrieved from http://www.craigkunce.com/cdt/cdt_samples/oehninger_barbara_sp2012.pdf

Todor, R. D. (2016). Blending traditional and digital marketing. Bulletin of the Transilvania University of Brasov, 9(1), 51-6. Retrieved from http://web.a.ebscohost.

Varas, C. (2010, July). Marketing Móvil. Universidad Abierta Interamericana. 